\title{
Parachuting harnesses comparative evaluation on energy distribution grids
}

\author{
Paula Karina Hembecker ${ }^{\mathrm{a},{ }^{*}}$, Ângela Regina Poletto ${ }^{\mathrm{b}}$ and Leila Amaral Gontijo ${ }^{\mathrm{c}}$ \\ ${ }^{a}$ Engineering Post-Graduation Program, Federal University of Santa Catarina, Valdivia St., n.387, 80040-260, \\ Curitiba, Paraná, Brazil \\ ${ }^{\mathrm{b}}$ Florianópolis Campus, Federal Institute of Santa Catarina, Mauro Ramos Av. ,n. 950, Florianópolis, Santa \\ Catarina, Brazil \\ ${ }^{\mathrm{c}}$ Engineering Post-Graduation Program, Federal University of Santa Catarina, University Campus - Trindade, \\ Florianópolis, Santa Catarina, Brazil
}

\begin{abstract}
This research aims to make a comparative evaluation of three different parachuting harnesses to work at heights in the energy industry, from the electricians' point of view concerning these products under the optics of usability and ergonomic principles, and mainly justified by the high quantity of injuries at the energy industry due to high falls. According to its main target, this field research is classified as exploratory-descriptive transversal viewing study and, considering this perspective, the study was developed in four steps. Research results have enlightened the weakest spots and the potential improvement opportunities of these products, developed to assure safety of the work at heights to the energy industry, according to the opinion of the users. Still, results point that, regardless of the model, these devices have adapting issues to fulfill the electrical sector user's needs.
\end{abstract}

Keywords: Electricity sector, parachuting harnesses, work at heights, energy distribution grids

\section{Introduction}

In Brazil, the main source of generation of electrical energy comes from hydroelectric power units (representing around $90 \%$ of the total), consequence of Brazil's river basins vast hydroelectric potential, estimated in more than 150 million kilowatts $(\mathrm{kW})$. Brazil has 673 sites altogether, with an installed capacity of over 76 thousand $\mathrm{kW}$. After generation, the electrical energy is transmmited to the distribution centres, which concentrate their activities on the final supplying process to the consumer (CREDER, 2007).

From all the areas in the electricity segment, energy distribution is the one that concentrates the largest share of the workforce, and is also the segment with the largest quantity and diversity of activities, which can be carried out on energised systems and on systems without active energy (BRAZIL, 2002a). In Brazil, there are 64 companies that are responsible to attend the market distribution of electricity, both private and state-owned. Together they supply energy to about 51 million consuming units, among which $85.18 \%$ belongs to the residential class (ABCE, 2008; ANEEL, 2010).

Services carried out in electricity distribution lines are considered complex and many are the factors that have a bearing on the occurrence of work accidents. It is mainly an outdoor fieldwork and in addition to the naturally inherent risks from electricity contact (NASCIMENTO et al., 2002; CAWLEY and HOMCE, 2003; MÄKINEN and MUSTONEN, 2003; FORDYCE et al., 2007), the workers that stay in direct contact with the electrical power system are permanently exposed to the risk of accidents arising from working at heights (CRANE, 1998; GUIMARÃES, FISCHER and BITTENCOURT, 2004), to biomechanical factors (EPRI, 2001; MARKLIN et al., 2004; MORIGUSHI et al., 2009), to physical and

${ }^{*}$ Corresponding author. E-mail: pkhembecker@yahoo.com.br. 
environmental problems (MELO et al., 2003) and are also subjected to embarrassment regarding job organisational factors (BOURGUIGNON et al., 2001; GUIMARÃES, SAURIN and FISCHER, 2004a).

Surprisingly, accidents caused by exposure to electricity are not the most common among electricians. According to studies, falls resulting from level differences, physical overexertion and impacts suffered by the workers have been identified as the main causes of injury in electricity companies (CRANE, 1998; EPRI, 2007; FUNCOGE, 2009).

In fact, accidents caused by falls from level differences are a major cause of morbidity and mortality within the electricity industry. In 2008, the main types of typical accidents with loss of working time in the segment were: floor level difference falls (18.57\%); impacts suffered by a person (16.44\%); reactions of the body to its movements $(10.85 \%)$ and same level falls (10.51\%). Accidents caused through exposure to electrical energy at low and high voltage worked out at $5.80 \%$ of the total types of accidents with loss of working time. The most common injuries in typical accidents with loss of working time include distortions, sprains, crushing and fractures (52.68\%), caused by agents in no relation with electricity at all (FUNCOGE, 2009).

Falls from heights accident prevention is a matter of concern not only for the workers and employers, but also for health and safety professionals. Within this context, there is full justification for the ergonomic efforts in seeking specific measures for intervention, such as the adaptation and improvement of work equipment, in the present situation of the safety equipment for work at heights, necessary to control the risks that are present and also reduce the damage to workers' health. However, development of products focused only on technical excellence is not enough; an evaluation of the product taking in consideration principles of ergonomics and usability is of great importance, chasing to meet the needs of the users in a pratical situation of use.

\section{The parachuting harness}

Human body is not resistant enough to support unexpected falls without suffering significant harm. The capability of kinetic energy absorption of the human body - as a result of an impact from a fall - is limited. When an $80 \mathrm{~kg}$ worker suffers a free fall of four meters, the result is a total impact force of over 3,000 joules to be absorbed (HSE, 2002).
The risk of injury is directly proportional to the height of the fall, and whenever the fall is from a height of more than two or three meters, the resulting injusire are often serious or even fatal (GOODACRE et al, 1999). Workers of overhead distribution lines usally operate at heights of more than two meters when carrying out their routine tasks. Thus, Brazilian legislation requires not only the use of basic protection equipment but also the use of a safety set when working at heights for tasks performed more than two meters above the ground and also in any situations where there is a risk of fall.

The main purpose of a protection system against falls from heights is to limit an user's fall and must must be composed, at least, by an anchorage body device which establishes connection with a lifeline. The equipment must not cause any discomfort, whether during the execution of the tasks, or during an accidental fall, or even while awaiting assistance after a fall (HSE, 2002). Some safety harness have multifunctional characteristics, which means that they are designed both for their primary function, the prevention of a possible fall from height, as well as additional purposes such as work positioning - which is the case of parachuting harnesses designed for working at heights within the electricity industry.

The personal fall-arrest system for working at heights, including the parachuting harness, is considered as a Personal Protection Equipment (PPE). In Brazil, the minimum requirements that must be met by personal protection equipment are described in the standards NR6 and more specifically in NR18, which refers specifically to safety equipment for working at heights in the construction industry. Requirements and methods for trials of safety belts (abdominal and parachuting harnesses) are specified by the Brazilian Technical Standards Association (ABNT, 2001), by technical standard NBR 11370:2001 - personal protection equipment: safety harness. According to this standard, the parachuting harness, as a component of a system to protect against falls, shall be adjustable and also, when attached to the user's body, it shall allow the distribution of supporting and stoppage forces, over the thighs, waist, chest and shoulders (ABNT, 2001).

The parachuting harness consists of the following elements:

- primary straps: these are the straps of the harness intended to sustain the body during the fall and also to prevent it; 
- secondary straps: other straps of the parachuting harness, which do not have the functions of sustenance or detention;

- anchorage elements for protection against falls: these are connection points of the harness, situated in the sternal and dorsal regions, to connect the harness up to a safety system to avoid a possible fall;

- anchorage elements for position: connection points of the harness along the abdominal line, for connecting the harness to a safety system for positioning and also distance restriction;

- waist belt support: a support which goes around the lumbar region through to the iliac crests;

- buckles: metallic components for anchorage or adjustment the size of the belt to the body of the user.

\section{Methodological Procedures}

This field research is classified as exploratorydescriprive transversal viewing study delineation and has been carried out in four steps:

- Step 1: a bibliographical and document research about the issue;

- Step 2: tasks analysis through direct and systematic observation, carried out by the electricians who work in overhead lines electricity distribution, regarding the use of the safety equipment for working at heights;

- Step 3: semi-structured interviews were conducted with 8 electricians from the company to collect specific information about the daily use of the product researched, from the standpoint of the users;

- Step 4: an investigation into how the interviewed electricians see the use of products, through the application of a questionnaire to the sample population. This questionnaire was divided into three parts, with a total of 11 objective questions and 1 subjective question, covering the following aspects: profile of the users; characteristics of the usage of the product and the subjective question about the potential and limitations on the use of the product.

\subsection{Parachuting Harnesses selected for the research}

The choice for carrying out this study was to choose three different models of parachuting harnesses, refered in it as A, B and C. All the models used in the study have been approved by the Brazilian Ministry for Labour and Jobs (MTE) and also have the respective Approval Certificate for Personal Protection Equipment (CA).

In the research, is used only one type of lanyard, so as not to interfere with the object of the study as here defined: the parachuting harness. The selected lanyard has a rope with a diameter of $16 \mathrm{~mm}$ and length of 1.80 meters, coated with plastic of 0.65 meters for the mechanical protection. The adjustment system of the straps consists of metallic and plastic components, while the attachment system is made through a carabiner double locking0.

The characteristics of the different models of parachuting harnesses (A, B and C) are shown in charts 1 , 2 and 3 , respectively.

Chart 1

Technical Characteristics of Parachuting Harness - Model A

$\begin{array}{ll}\text { Colour } & \text { Black } \\ \text { Weight } & 2.10 \mathrm{Kg} \\ & 5 \text { double aluminium buckles: } \\ & \text { - Waist }(2) \rightarrow \text { from } 0.82 \text { to } 1.40 \mathrm{~m} \\ \begin{array}{c}\text { Adjustment } \\ \text { System }\end{array} & \text { • Sternal }(1) \\ & \text { - Legs }(2) \rightarrow \text { from } 0.50 \text { to } 0.78 \mathrm{~m} \\ \text { Anchorage } & \text { Sternal, lateral and dorsal } \\ \text { Points } & \\ \text { Primary } & \text { Polyamide } \\ \text { Straps } & \\ \text { Waist Belt } & \text { • Foam padded waist straps }(0.63 \times 0.95 \mathrm{~m}) \\ \text { Support } & \text { • } 2 \text { side positioning rings }\end{array}$

The model A parachuting harness has four anchor points, one on the chest (sternal), two at the sides (lateral) and one at the back (dorsal). The primary and secondary straps are made from polyamide strands. The waist and legs pads are lined with polyamide fabric. The waist and leg straps have a regulation system through double aluminium buckles. 
Chart 2

Technical Characteristics of Parachuting Harness - Model B

\begin{tabular}{|c|c|}
\hline & MODEL B \\
\hline Colour & $\begin{array}{l}\text { Black with embellishments on primary } \\
\text { straps, weft in blue and orange }\end{array}$ \\
\hline Weight & $1.75 \mathrm{~kg}$ \\
\hline $\begin{array}{c}\text { Adjustment } \\
\text { System }\end{array}$ & $\begin{array}{l}5 \text { double aluminium buckles: } \\
\text { - Waist }(1) \rightarrow \text { from } 0.68 \text { to } 1.08 \mathrm{~m} \\
\text { - Sternal (2) } \\
\text { - Legs }(2) \rightarrow \text { from } 0.35 \text { to } 0.98 \text { meters }\end{array}$ \\
\hline $\begin{array}{c}\text { Anchorage } \\
\text { Points }\end{array}$ & Sternal, lateral and dorsal \\
\hline $\begin{array}{l}\text { Primary } \\
\text { Straps }\end{array}$ & Polyamide \\
\hline $\begin{array}{l}\text { Waist Belt } \\
\text { Support }\end{array}$ & $\begin{array}{l}\text { - Foam padded waist straps } \\
(0.69 \times 0.19 \mathrm{~m}) \\
\text { - } 2 \text { side positioning rings } \\
\text { - } 2 \text { side sustaining points for tools }\end{array}$ \\
\hline
\end{tabular}

The model B has four anchor points, one on the chest (sternal), two at the sides (lateral) and one at the back (dorsal). It consists of two polyamide primary strands, that enwrap the user's legs and allow adjustment of lenth. These are connected using double aluminium buckles, which have a resistance of more than 1,500 daN. This type of harness has a higher waist belt support ( 0.19 meters $)$ when compared to the other selected models.

Table 3

Technical Characteristics of Parachuting Harness - Model C

$\begin{array}{cl}\text { Colour } & \text { B } \\ \text { Weight } & 2,00 \mathrm{Kg} \\ & 5 \text { double zincked steel buckles: } \\ & \text { - Waist }(1) \rightarrow \text { from } 0.75 \text { to } 1.25 \mathrm{~m} \\ \begin{array}{c}\text { Adjustment } \\ \text { System }\end{array} & \bullet \quad \text { Sternal }(1) \\ & \bullet \quad \text { Legs }(2) \rightarrow \text { from } 0.41 \text { to } 0.78 \mathrm{~m} \\ \begin{array}{c}\text { Anchorage } \\ \text { Points }\end{array} & \text { Sternal, ventral, lateral and dorsal } \\ \begin{array}{c}\text { Primary } \\ \text { Straps }\end{array} & \text { Polyamide }\end{array}$

- Foam padded and non deforming waist straps, coated in transpirable fabric $(0.69 \times 0.15 \mathrm{~m})$

- 2 side positioning rings

- 2 side sustaining points for tools

The model $\mathrm{C}$ has five anchor points, one on the chest (sternal), one at the front (ventral), two at the sides (lateral) and one at the back (dorsal). The foam padded waist and legs straps are made from transpirable fabric and filled with non-deforming foam. The adjustment system is made through five buckles made of zincked steel.

Figure 1

Models A, B and C - parachuting harnesses

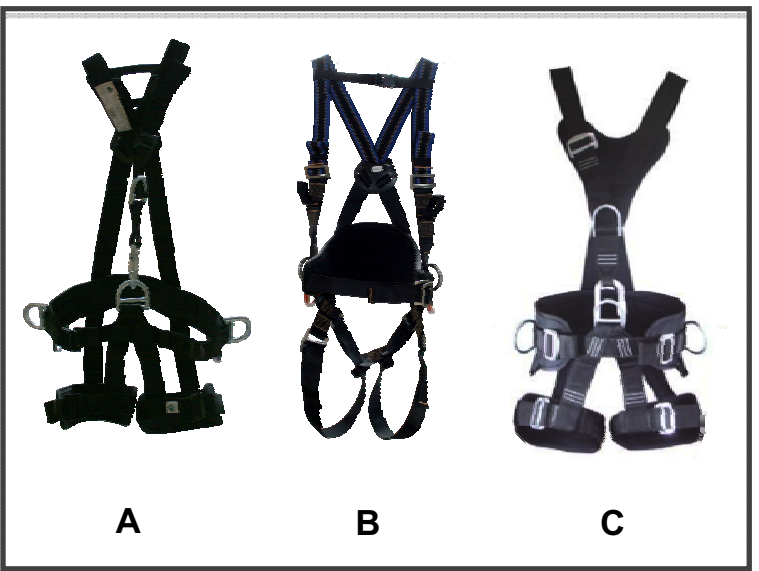

\section{Place of Study}

The field research was conducted at a small electric power utility, located in the metropolitan area around Curitiba, the capital of Paraná. This is a closed-capital limited company controlled by the municipal government and also follows the recommendations set by the Brazilian Regulatory Body of the Electricity Segment (ANEEL), part of the Ministry for Mines and Energy, which in turn is the federal institution which is responsible for checking and regulating all the electric power industry of the country.

The area of concession of this company covers a land area of some $1,192 \mathrm{~km}^{2}$ and serves more than 38,800 consumer users, most of which $(87.9 \%)$ are from the residential segment, in a city with a population of more than 100 thousand people. The electric 
power utility operates within an electrical system consisting of a substation with an installed power of 41.67 MVA and a total of $1,190 \mathrm{~km}$ and $1,418 \mathrm{~km}$ of high and low voltage transmission lines respectively, both rural and urban.

The company is operated by a total workforce of 107 employees, divided among the administration and operational divisions. Specifically, the operational divisions have 48 employees in three separate areas of activity.

\section{Subjects of the Sample}

The selection of the sample was made at random, within the group of employees working in the operational divisions and which work with the overhead distribution lines. Thus, the sample consisted of 8 electricians of the operational divisions of the company. All the people selected are male, with ages ranging from 22 to 40 .

Table 1

Survey Sample Profile

\begin{tabular}{|c|c|c|}
\hline VARIABLE & $\begin{array}{l}\text { FREQUENCY } \\
\text { (n) }\end{array}$ & $\%$ \\
\hline \multicolumn{3}{|l|}{ GENDER } \\
\hline Male & 8 & 100 \\
\hline \multicolumn{3}{|l|}{ AGE } \\
\hline 20 to 29 & 4 & 50 \\
\hline 30 to 39 & 3 & 37.5 \\
\hline 40 to 49 & 1 & 12.5 \\
\hline \multicolumn{3}{|c|}{ EDUCATIONAL LEVEL } \\
\hline $\begin{array}{l}\text { Completed High } \\
\text { School }\end{array}$ & 8 & 100 \\
\hline \multicolumn{3}{|c|}{ BODY MASS INDEX - BMI } \\
\hline $\begin{array}{c}\text { Normal Weight } \\
\left(18.5 \text { to } 24.9 \mathrm{Kg} / \mathrm{m}^{2}\right)\end{array}$ & 4 & 50 \\
\hline $\begin{array}{c}\text { Overweight } \\
\left(25 \text { to } 29.9 \mathrm{Kg} / \mathrm{m}^{2}\right)\end{array}$ & 2 & 25 \\
\hline $\begin{array}{c}\text { Obesity } \\
\left(30 \text { to } 34.9 \mathrm{Kg} / \mathrm{m}^{2}\right)\end{array}$ & 2 & 25 \\
\hline VARIABLE & MEAN & VARIATION \\
\hline HEIGHT & 1.73 meters & $\begin{array}{l}1.65-1.84 \\
\text { meters }\end{array}$ \\
\hline WEIGHT & $75.5 \mathrm{~kg}$ & $55-104 \mathrm{~kg}$ \\
\hline $\begin{array}{l}\text { TIME WITH THE } \\
\text { COMPANY }\end{array}$ & $\begin{array}{l}5 \text { years and } 9 \\
\text { months }\end{array}$ & $\begin{array}{l}1 \text { year and } 2 \\
\text { months - } \\
20 \text { years }\end{array}$ \\
\hline
\end{tabular}

\begin{tabular}{l|c|c}
\hline $\begin{array}{l}\text { EXPERIENCE AS } \\
\text { AN ELECTRICIAN } \\
\text { working with over- } \\
\text { head distribution } \\
\text { lines }\end{array}$ & $\begin{array}{c}\text { years and } 4 \\
\text { months }\end{array}$ & $\begin{array}{c}1 \text { year and 10 } \\
\text { months - } \\
18 \text { years }\end{array}$ \\
\hline $\begin{array}{l}\text { EXPERIENCE } \\
\text { WITH THE PROD- } \\
\text { UCT } \\
\text { parachuting harness }\end{array}$ & $\begin{array}{c}1 \text { year and 6 } \\
\text { months }\end{array}$ & $\begin{array}{c}1 \text { year and 2 } \\
\text { months - } \\
3 \text { years }\end{array}$ \\
\hline
\end{tabular}

The subjects participating in the research had experience of more than one year in the use of parachuting harnesses. They received two new types of parachuting harnesses and used them for one week in routine work tasks in overhead distribution lines.

\section{Comparative Analysis of Elements and Characteristics of the Types of Parachuting Harnesses as Used}

The results for the comparative analysis of the characteristics and elements that define the three types of parachuting harnesses as selected were obtained through the tasks analysis, conduction of semistructured interviews and also the application of questionnaires for the investigation of the perception of line workers about the products, in relation to the following items:

- Safety;

- Practical;

- Anchorage device for positioning adjustment;

- Anchorage device for protection against falls;

- Locking system;

- Work Posture;

- Waist belt support for positioning;

- Weight of the equipment;

- Quality of the material;

- Comfort

- Satisfaction

\section{Potential and Weaknesses}

At the end of the questionnaire, users were asked to give their opinion about negative and positive points concerning the use of the product models as tested. The data was compiled and then compared with the tasks analysis as carried out, with the results being shown in Chart 4, as follows. 
Chart 4

Main strengths and weaknesses regarding the use of the types of parachuting harnesses as here appraised

$\begin{array}{ll}\text { MODEL A } \\ \text { Strengths } & \text { Weaknesses } \\ \text { - safe; } & \text { Lower part of the } \\ \text { - comfortable; } & \text { wet when the electrician } \\ \text { - light weight; } & \text { has to wear it on rainy } \\ \text { days; } \\ \text { made of resistant } \\ \text { materials. }\end{array}$

Chart 4

Main strengths and weaknesses regarding the use of the types of parachuting harnesses as here appraised (cont.)

\begin{tabular}{|c|c|}
\hline \multicolumn{2}{|c|}{ MODEL C } \\
\hline $\begin{array}{l}\text { Strengths } \\
\text { - safe; } \\
\text { - comfortable; } \\
\text { - light weight; } \\
\text { - double aluminium buckles, } \\
\text { of the regulation system, is } \\
\text { of a practical and efficient } \\
\text { size; } \\
\text { - Waist and legs support } \\
\text { have lining in non- } \\
\text { deforming material and are } \\
\text { coated in special } \\
\text { transpirable fabric; } \\
\text { - angle between the work } \\
\text { positioning ring and the } \\
\text { belt makes it easier to fit in } \\
\text { the safety strap. }\end{array}$ & $\begin{array}{l}\text { Weaknesses } \\
\text { - Lower part of the } \\
\text { equipment still dirty and } \\
\text { wet when the electrician } \\
\text { has to wear it on rainy } \\
\text { days; } \\
\text { - Short strap joining the } \\
\text { abdominal belt and the } \\
\text { thigh holder which } \\
\text { enwraps the users' legs; } \\
\text { - Made of material which } \\
\text { is not ignifugous. }\end{array}$ \\
\hline
\end{tabular}

\section{Recommendations}

Based on the results obtained according to methods and techniques applied to the study, general recommendations have been proposed, setting targets and principles for the design of a parachuting type harness within the electricity distribution segment. Recommendations that follow have been done based on criteria of ergonomics and usability, considering factors such as safety, efficiency, utility and comfort of the safety equipment.

1. Insert foam padded straps in the suspender around the shoulder region, made of non-deforming materials and coated with transpirable fabric.

Purpose: To provide greater comfort to the user by reducing the load on the shoulder region. 
2. Insert a system for setting up the length of the primary straps that attach the abdominal belt to the leg loops, enwrapping the user's leg.

Purpose: To provide height adjustability of the leg loops and also avoid lower limbs compression.

3. Insert clip type fastener buckles with a system for length adjusting of the leg loops straps.

Purpose: To make it easier to use the equipment and also to prevent it from remaining wet and dirty on rainy days.

4. Remove plastic materials that enwrap tool foothold, and then place it away from work positioning rings.

Purpose: To make it possible for the user to easily distinguish the texture of the materials that are part of the ring and the tool foothold, thus avoiding the possibility of the worker confusing the location reserved for the anchorage of the lanyard.

5. Adapt a bag for holding tools and other materials normally used in the electricians' work routine.

Purpose: To avoid the tools and other materials falling when they are placed in an improvised form at the support points of the abdominal belt.

6. Produce the security equipment using materials that have ignifugous properties.

Purpose: To add ignifugous properties to the equipment used within the electricity industry.

7. Insert a label holder at the front of the suspender of the parachuting harness.

Purpose: To attach a card with identification data of the employee, including the name and the blood group of the user.

8. Insert reflective strips on the suspender and also in the rear part of the lumbar region.

Purpose: To provide visibility for electricians who work at night.

Figure 2

Recommended parachuting harnesses model

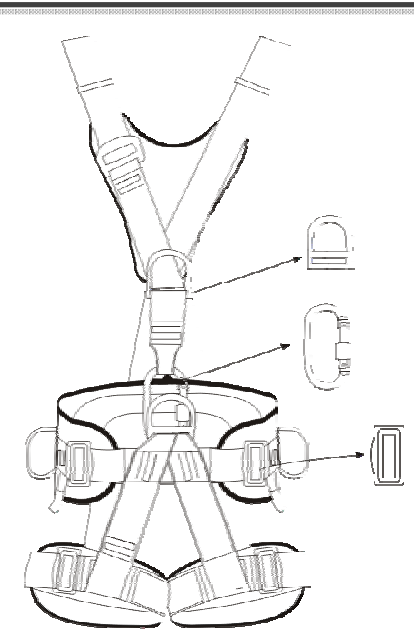

\section{Final Comments}

Based on the results of the survey, the parachuting harnesses selected have differences between them in several different aspects concerning ergonomics and usability, and also that there is evidence of the main strengths and weaknesses of these products developed to ensure safety when working at height in the electricity segment, according to the perception of the user. The results also show that, regardless of the model, the equipment assessed need adjustment to serve the user working within the context of the electricity industry.

Due to the complexity and diversity of the tasks of the electricity distribution industry, this being a segment characterised by the high rates of work accidents, the intensification of the studies about issues concerning the work of the electricians active in this area is essential, specifically with regard to those aspects that involve ergonomics and usability of tools and safety equipment. The contribution made by this survey lies in the collection of data about the tasks pursued by the electricians who work for an distribution electric power utility, and also in the identification of the needs of these workers in relation to issues concerning work at height. The approach taken by this academic study has brought up some general recommendations based on problems that have been diagnosed, in relation to the use of models of safety equipment as evaluated in the context of the electricity segment.

Based on the execution of this survey, it was proposed, as a recommendation for future studies, the execution of tests with a prototype of the parachuting harness as proposed, with the target public, under real conditions of use, together with the analysis of the feedback supplied by the users and an analysis based on quantitative measurement of physical workload. In this research, it has decided to limit and develop an approach, within the electricity distribution segment, specifically in one distribution electric power utility. However, the rate of occurrence of accidents with serious or fatal consequences in subcontractors, outside the scope of the present study, is also high. Thus, 
we suggest that there should be the collection of data from electricians who work at height in outsourcers.

\section{References}

[1] ANEEL. Agência Nacional de Energia Elétrica. Informações Técnicas: mercados de distribuição [online]. [ANEEL. National Electrical Energy Agency. Technical Information: distribution markets] Available at http://www.aneel.gov.br/area.cfm?idArea=48\&idPerfil=2. Accesed on 27 July 2011.

[2] ANSI. American National Standards Institute. ANSI Z359.12007: safety requirements for personal fall arrest systems, subsystems and components. Illinois: American Society of Safety Engineers, 2007.

[3] M. Amphoux. Exposure of Human Body in Falling Accidents. International Fall Protection Seminar, Toronto, 1983. In: Health and Safety Executive. Harness Suspension: review and evaluation of existing information. Health and Safety Executive: Inglaterra, 2002.

[4] ABCE. Associação Brasileira de Concessionárias de Energia Elétrica. Setor Elétrico Brasileiro: informações básicas. [ABCE. Brazilian Association of Electricity Concessionaires. The Brazilian Electricity Segment: Basic Information] ABCE, 2008. Available

http://www.abce.locaweb.com.br/downloads/setoreletricobrasi 1_13marco2008.pdf. Accessed on 27 July 2010.

[5] ABNT. Associação Brasileira de Normas Técnicas. NBR 11370. Equipamentos de Proteção Individual - Cinturão e Talabarte de Segurança: especificação e métodos de ensaio. [ABNT. Brazilian Technical Standards Association. NBR 11370. Personal Protection Equipment - Security Straps and Belts: specifications and Trial methods] Rio de Janeiro: Associação Brasileira de Normas Técnicas, 2001.

[6] D.R. Bourguignon, et al. Perfil dos Eletricistas do Setor Energético no Espírito Santo: um estudo de base ergonômica. [A profile of the electricians of the energy sector in the state of Espírito Santo, Brazil] In: Anais do XI Congresso Brasileiro de Ergonomia [Annals of the $11^{\text {th }}$ Brazilian Ergonomics Congress], Gramado, 2001.

[7] J.C. Cawley; G.T. Homce. Occupational Electrical Injuries in the United States, 1992-1998, and Recommendations for Safety Research. Journal of Safety Research, v.34, p.241-248, 2003.

[8] M. Crane. Produccion y Distribuicion de Energia Electrica [Production and Distribution of Electrical Energy] In: Enciclopedia de Salud y Seguridad en el Trabajo. [Encyclopaedia of Health and Safety in the Workplace] Madrid: Ministerio de Trabajo y Asuntos Sociales [Ministry for Labour and Social Affairs], v.3, 1998.

[9] H. Creder. Instalações Elétricas [Electrical Installations]. $15^{\text {th }}$ edition. Rio de Janeiro, LTC, 2007.

[10]CSA. Canadian Standards Association. CAN/CSA - Z259.10M90: Full Body Harnesses. Ontario: Canadian Standards Association, 2006.

[11]ECS. European Committee for Standardisation. EN:361:2002 personal protective equipment against falls from a height - full body harnesses. European Committee for Standardisation, 2002.

[12]EPRI. Electric Power Research Institute. Ergonomics Handbook for the Electric Power Industry: overhead distribution line workers intervention. California: Electric Power Research Institute, 2001.

[13]_. Annual Report 2007: occupational health and safety trends among electric energy workers, 1995-2007. California: Electric Power Research Institute, 2007.

[14]T.A. Fordyce, et al. Thermal Burn and Electrical Injuries Among Electric Utility Workers, 1995 - 2004. Burns, v.33, p.209-220, 2007.

[15]FUNCOGE. Fundação Comitê de Gestão Empresarial. [CORPORATE MANAGEMENT COMMITTEE FOUNDATION] Relatório 2008: estatísticas de acidentes do setor elétrico brasileiro. [2008 Report: statistics regarding accidents of the Brazilian electricity segment] Rio de Janeiro: COGE Foundation, 2009.

[16]L.B.M. Guimarães; D. Fischer; L.I.H. Bittencourt. Avaliação da Carga de Trabalho de Eletricistas em Três Sistemas para Subida em Poste. [Assessment of Workload of Electricians in Three Systems for Climbing Lamp Posts] In: Anais do XIII Congresso Brasileiro de Ergonomia [Annals of the $13^{\text {th }}$ Brazilian Ergonomics Congress], Fortaleza, 2004.

[17]L.B.M. Guimarães; T.A. Saurin; D. Fischer. Integração de Fatores Humanos no Planejamento da Produção de Equipes Pesadas de Eletricistas. [Integration of Human Factors in the Planning of Production for Heavy Teams of Electricians] In: Anais do XXIV Congresso Nacional de Engenharia de Produção [Annals of the $24^{\text {th }}$ National Production Engineering Congress], Florianópolis, 2004a.

[18]HSE. Health And Safety Executive. Falls from Height: prevention and risk control effectiveness. Sudburry: HSE Books, 2003.

[19]_. Harness Suspension: review and evaluation of existing information. Inglaterra: Health and Safety Executive, 2002.

[20]ISO. International Standards Organisation. ISO 10333-1:2000: personal fall-arrest systems. Part 1: full body harnesses. Geneva: International Standarts Organisation, 2000.

[21]H. Mäkinen; S. Mustonen. Features of Electric Arc Accidents and Use of Protective Clothing in Finland. Safety Science, v.41, p.791-801, 2003.

[22]R.W. Marklin; L. Lazuardi; J.R. Wilzbacher. Measurement of Handle Forces for Crimping Connectors and Cutting Cable in the Electric Power Industry. International Journal of Industrial Ergonomics, v.34, p.497-506, 2004.

[23] L.A. Melo; G.B.A. Lima; N.D. Gomes; R. Soares. Segurança nos Serviços Emergenciais em Redes Elétricas: os fatores ambientais. [Safety in Emergency Services in Electricity Networks], Produção Magazine, 2(13):88-101, 2003.

[24]C.S. Morigushi. et al.Sintomas Músculoesqueléticos em Eletricistas de Rede de Distribuição de Energia. [Muscular and Skeletal Systems in Electricians from the Energy Distribution Network] Revista Brasileira de Fisioterapia [Brazilian Physiotherapy Magazine], São Carlos, 2009.

[25]J.O. Nascimento, et al. Análise de Alguns Fatores de Risco Associados ao Serviço de Emergência de uma Empresa do Setor de Distribuição de Energia Elétrica do RJ. [Analysis of Some Risk Factors Associated to the Emergency Services of an Electrical Energy Distribution Company in Rio de Janeiro] In: Anais do XXII Encontro Nacional de Engenharia de Produção [Annals of the $22^{\text {nd }}$ National Meeting on Production Engineering], Curitiba, 2002. 